\title{
Auditor awareness of earnings management
}

\section{Evangelos Koumanakos*}

National Bank of Greece, Credit Division, 262 21, Patras,

GR 26221 Greece

Email: Koumanakos.E@nbg.gr

and

Department of Economics, University of Ioannina, P.O. Box 1186,

45110 Ioannina, Greece

Email: ekoumanakos@cc.uoi.gr

*Corresponding author

\section{Antonios Georgopoulos and Costas Siriopoulos}

Department of Business Administration, University of Patras, University Campus Rio, P.O. Box 1391, Patras 26500, Greece

Email: georgop@upatras.gr Email: siriopoulos@upatras.gr

\begin{abstract}
This study examines whether auditor reporting in Greece is associated with different levels of discretionary accruals - a common proxy for earnings management. We focus our research on 91 cases of quoted companies on the Athens Stock Exchange (ASE). These are listed companies that were asked in year 2003 by the Athens Stock Exchange Board to quantify the effects of the qualifications made by their external auditors and post them in the ASE website. Those auditors' reports were referred to published financial statements of the year 2002. By employing some variations of the traditional Jones-discretionary accrual model, we document that several major Greek companies in financial distress with qualified audit opinions do appear to manipulate their reported earnings by exploiting the weaknesses of the Greek GAAP.
\end{abstract}

Keywords: auditing; earnings management; financial distress; Greece; qualified opinions.

Reference to this paper should be made as follows: Koumanakos, E., Georgopoulos, A. and Siriopoulos, C. (2008) 'Auditor awareness of earnings management', Accounting, Auditing and Performance Evaluation, Vol. 5, No. 1, pp.50-65.

Biographical notes: Evangelos Koumanakos is a Credit Underwriter in the National Bank of Greece. His research interests relate to financial reporting, banking and auditing issues. He has published articles in such journals as International Review of Financial Analysis, Review of Development Economics, and Managerial Auditing Journal, and his research has been presented in many international conferences.

Antonios Georgopoulos is Assistant Professor of Financial Accounting at the Faculty of Business Administration, University of Patras, Greece. His present 
research interests include mergers and acquisitions, accounting policies of transnational corporations and management decisions.

Costas Siriopoulos is a Professor of Financial Econometrics at the University of Patras, Greece. His research interests include financial markets, time-series analysis and econometrics. He has published articles in such journals as International Journal of Finance and Economics, Multinational Finance Journal, Applied Financial Economics, Managerial and Decision Economics, and Economic Notes, and his research has been presented in many international conferences.

\section{Introduction}

Earnings management and accounting fraud have received significant attention during the last few years. Recent accounting scandals at prominent companies such as Enron, WorldCom, Parmalat and Ahold appear to have shaken the confidence of investors internationally.

According to Healy and Wahlen (1999), "earnings management occurring when managers use judgment in financial reporting and in structuring transactions to alter financial reports to either mislead some stakeholder about the underlying economic performance of the company, or to influence contractual outcomes that depend on reported accounting numbers".

While many researchers have examined earnings management motivations, few studies have investigated the role of auditors in potentially approving earnings management. Several factors influence the auditors' subjective judgment in evaluating the interpretation of generally accepted accounting principles (GAAP) by client management who may have incentives that bias the interpretation of GAAP to achieve target earnings.

Focusing on the incentives that managers of firms have to engage in corporate earnings management, many motivations have been put forward in the related growing literature ${ }^{1}$ such as: the maximisation of their own compensation via earnings-based bonus plans; the minimisation of political or regulatory costs; the avoidance of default on debt contracts; the minimisation of the renegotiation costs of debt contracts in the event of default; and meeting or beating earnings benchmarks.

Recently, regulatory authorities in the USA with the passage of the Sarbanes Oxley (SOX) Act on 30.7.2002 attempted to protect investors by improving the accuracy and reliability of corporate disclosures by modifying governance, reporting and disclosure rules for public companies, increasing criminal and civil liability for securities fraud, and creating a new oversight board for independent audit firms engaging in various non-audit services for their clients.

Our study investigates whether auditor reporting in Greece is associated with different levels of discretionary accruals (proxy for earnings management) and the effect of both the size of the auditor quantifiable qualifications and financial distress (measured by Altmans' score) to earnings management adoption. This paper is different from other studies since it examines directly the role of auditors in the detection of earnings management. Moreover the emphasis is placed into the information content of the auditor's reports. 
The contribution of the study is also that it provides additional evidence on the controversial issue of what factors drive the auditor's opinion and accruals relation.

Thus, we focus our research on 91 cases of 'suspects' for earnings manipulation companies, quoted on the Athens Stock Exchange (ASE), that in June 2003 were obliged by the Athens Stock Exchange Board to quantify the effect of the qualifications made by their external auditors and present them analytically in the website address of ASE so as to enable potential investors to form a clearer view about each of these firm's financial position. We label these firms 'suspect' because there are only suspicions that they have carried out misleading reporting and discretionary or unexpected accruals decisions.

The remainder of the paper is organised as follows. In the second section, we have conducted a critical review of the empirical literature relative to the association of earnings management and the audit opinions. Section 3 presents an overview of the institutional background of the Greek audit services market Section 4 presents the data used. Section 5 develops our hypotheses while Section 6 discusses research design, including model specification and empirical results. The final section concludes the paper.

\section{Previous literature}

The literature on auditor characteristics suggests that auditors provide two valuable roles to capital market participants: an information role and an insurance role. Auditors provide independent verification of manager prepared financial statements and can discover and report breaches in a client's accounting system (DeAngelo, 1981). As such, audit quality contributes to the credibility of financial disclosure, and reduces the cost of capital.

Several studies have examined how auditing affects earnings management. For example, Becker et al. (1998) tested the effect of audit quality on earnings management through discretionary accruals and found that discretionary accruals of clients of Big 6 auditors are lower than discretionary accruals of clients of non-Big 6 auditors. However, they did not test for income-decreasing discretionary accruals but only for income-increasing earnings management. Bauwhede et al. (2000) documented that audit quality and public ownership act as constraints on income decreasing earnings management but not on income-increasing earnings management in Belgium. Kinney and Martin (1994) reviewed nine studies and concluded that auditing reduces positive bias in pre-audit net earnings and net assets. Hirst (1994) also demonstrated that auditors are sensitive to earnings manipulations through both income-increasing accruals and income-decreasing accruals, and that they are able to detect management incentives to manipulate earnings. Francis and Krishnan (1999) provided additional evidence on the relation between audit opinions and accruals. Specifically they showed that firms with large absolute accruals are more likely to have qualified audit opinions and show that this result is strongest for firms with extremely large negative accruals. They also provided evidence suggesting a negative relation between accruals and audit opinions, but argue that this relation may not be linear. Bartov et al. (2000) compared the power of various accrual models in detecting earnings management under the assumption that firms receive certain modified opinions because they engage in extreme earnings management.

Bradshaw et al. (2001) found no evidence that auditors signal the future earnings problems associated with high accruals through either their audit opinions or through auditor changes. Thus their findings indicated that auditors do not alert investors to the 
future earnings problems associated with high accruals. Evidence in Nelson et al. (2002) suggests that auditors and management virtually always resolve earnings-management issues before opinions are issued. They report the results of a survey of 253 audit partners and managers of a Big 5 firm, who describe 515 specific incidences of potential earnings management detected during the course of their audits.

More recently, Butler et al. (2004) in assessing whether qualified opinions are a function of earnings management found no evidence that auditors use their opinions to alert financial statement users of either excessive earnings management or the consequences of high positive accruals. They found instead that the modified opinion/abnormal accruals relation stems from companies with going-concern opinions, because such companies have negative abnormal accruals. In general, the findings of Butler et al. are inconsistent with earnings-management and auditor-conservatism explanations for the audit opinion/abnormal accruals relation.

Finally Chung et al. (2005) documented that low-growth companies with high free cash flow use income increasing discretionary accruals to camouflage the earnings impact of non-value-maximising investments but Big-6 auditors, due to their conservatism and their desire to avoid litigation, by deterring managers' opportunistic earnings management, moderate this effect.

Examining earnings-management issues in Greece seem to be of great importance after the results presented by two recent international studies - the only two among others which include Greece in their sample. ${ }^{2}$ Both studies conclude that earnings management is more pronounced in Greece than in other countries.

Specifically, Leuz et al. (2003), based on financial accounting data from 1990 to 1999 for 8616 non-financial firms from 31 countries, created four proxies to measure the pervasiveness of earnings-management practices engaged in each country. Their analysis suggested that outsider economies with dispersed ownership, strong investor protection, and large stock markets exhibit lower levels of earnings management than insider countries with relatively concentrated ownership, weak investor protection, and less developed stock markets. Greece is found to possess the highest mean aggregate earnings management score (28.3) while USA has the lowest (2.0). Bhattacharya et al. (2003) in a complementary paper and using a sample of 58.653 firm-years observations from 34 countries for the period 1986-1998, constructed a panel data set for three dimensions of earnings opacity: ${ }^{3}$ earnings aggressiveness, loss avoidance and earnings smoothing. Consistent with Leuz et al., they combined these three dimensions to obtain an overall earnings opacity time-series measure per country, showing high ranks for Greece and countries such as South Korea and Indonesia and low ranks for countries such as the USA, Norway and Portugal.

\section{Overview of the Greek audit services market}

Since the late 1980s and early 1990s, the Greek government has introduced measures aimed at stabilising and improving the economy. This has resulted in steady growth in GDP. However, inflation rates and interest lending rates, which were as high as 30 and $20 \%$ respectively, did not start to fall significantly until the mid-1990s. In fact, as Oltheten et al. (2003) indicate, Greece's entry into the European Economic Community (EEC) in 1981 exhibited two very contrasting patterns. The first decade after entry was 
characterised by exposure to increased competition from other EU countries and presence of domestic populist policies while the combination of these two effects led to the deterioration of the country's economic performance and the divergence between Greece and its EU partners. During the second decade, a successful stabilisation of the Greek economy, mostly due to the external constraint imposed by the Convergence Criteria for participation in the EMU, restored economic growth.

Both Greek company law and the Accounting plan describe the form of presentation of corporate financial statements. The annual financial statements ${ }^{4}$ of entities satisfying specific criteria, stated by the codified business Law 2190/1920, must be audited by an independent auditing firm of certified auditors. Statutory auditing requirements were first legislated in Greece in 1931 but in practice the Greek audit services market could be dated from 1955 with the establishment of the state-controlled Body of Sworn-in Accountants (SOL). As Caramanis (1998) notes, SOL had centralised control over audit assignments enjoying a monopoly in the market for statutory audits while its main objective was the protection of the public interest. Ballas (1999) and Caramanis (1999) review the political and professional conflicts that eventually led to the regulatory reform with the liberalisation of the audit market accomplished in 1992.

Certified auditors in Greece qualify their report whenever they think there exists material influence on specific items or on the overall picture of the financial statements, or a limitation in their possibility to formulate a sufficient opinion. References to qualified audit reports have increased in frequency over the last few years internationally. As Spathis et al. (2003) note, audit qualifications in Greece have to do with accounting events where the Greek GAAP were not followed or were incorrectly applied, or the tax and other laws were followed instead of the business law L. $2190 / 1920^{5}$ for external reporting. In the opinion paragraph of the report, the auditor classifies his professional opinion as: unqualified, qualified, adverse, or disclaimer of opinion. ${ }^{6}$ Last years, anecdotal evidence ${ }^{7}$ in Greece has been devoted to recording cases of companies with severe qualifications in their auditor's report. In this context the Hellenic Capital Market Commission with a new regulation, in 1999, obliged all listed companies to quantify the effect of the qualifications made by the auditors and present them analytically in a separate paragraph of their annual report so as to enable potential investors to form a clearer view about each firm's financial position. In addition, more recently, responding to concerns over audit quality and the credibility of financial reporting voiced by anecdotal evidence and the financial statement users, the Greek Ministry of Economy with regulation N.3148/2003 established a new Committee $^{8}$ for external audit improvement with a mandate to propose a remedial action plan for improving auditor independence and services.

In general, it can be argued that while the introduction of the reforms, in post-liberalisation Greece, led to the development of the auditing profession, there are some aspects of the socio-economic environment that pose a threat to auditor independence and audit quality in Greece since many Greek companies tend to be closely held by a small number of shareholders, usually members of the same family, who typically exercise significant control over operations. This situation, usually, creates agency conflicts between controlling shareholders and minority shareholders and could motivate controlling shareholders to engage in opportunistic earnings management and hire auditors more acquiescent to their demands regarding accounting choices. 


\section{Data}

The event sample for this study consists of a group of 91 companies that in June 2003 were asked by the Hellenic Capital Market Commission and the Athens Stock Exchange Board to quantify the effect of the qualifications made by the external auditors to their previous year financial statements and present them analytically on an accessible, for all interested investors, website address of the Athens Stock Exchange (ASE). Apparently, this enforcement action of the Greek regulatory authorities can be viewed as an early 'red flag' highlighting the seriousness of the qualifications included in those 'suspect' firms auditors' reports. The majority of the above cases identified represent opportunistic reporting induced by earnings overstatements.

In order to investigate the existence and importance of earnings-management practices applied by these quoted companies, we compare their December year-ends, annual accounts, including the auditors' reports, to a control sample consisting of all other firms listed in 2002, whose audit reports did not contain material quantifiable qualifications ('non-suspect' firms).

We delete, from both event and control samples, quoted firms in the financial services industry (commercial banking, investment brokerage, insurance, etc) because the nature of accruals for firms in these industries differ from that in other industries. We also exclude initial public offerings (IPOs; 21) from the year 2002 since recent empirical evidence (Koumanakos and Tzelepis, 2004; Roosenboom et al., 2003; Teoh et al., 1998) indicate that IPOs tend to manipulate their earnings upward in the period around the listing. However, we do not eliminate from our analysis Greek listed firms engaged in merges and acquisitions (M\&A) or seasoned equity offerings (SEOs) taking place in the period under consideration because Greek empirical studies (Cohen et al., 2004; Koumanakos et al., 2005) indicate no evidence of earnings-management adoption around these events. Finally, elimination of firms with incomplete data and outliers leaves us with an event sample of 58 suspect firms as opposed to 232 non-suspect firms, which comprise our control sample.

Data on audit opinions and quantifications on the qualifications of auditors' reports for this study were obtained from the website of the ASE. ${ }^{9}$ Financial statements data for all listed firms were kindly provided by Hellastat S.A. Descriptive statistics for selected variables of sample firms are cited in Table 1.

As was expected, almost all financial variables (with the only exception being the leverage variable) selected proved to be significantly different $(p<0.05)$ amongst our two sub samples. Moreover the most pronounced difference was shown to be the ratio of ROA even before the restatements prescribed by auditors' opinions take place. Qualitatively similar were the results reported by Spathis (2003) for a sample of qualified and non-qualified firms, when he developed a model which provide information on the likelihood of a company's receiving a qualification given its financial and firm litigation data. 
Table 1 Selected financial characteristics of sample firms for the year 2002 excluding outliers $^{\mathrm{a}}$

\begin{tabular}{lccc}
\hline & 'Suspect' firms mean $(N=52)$ & Non-suspect firms mean $(N=218)$ & t-test for difference \\
\hline OCF & 0.256 & 0.289 & 1.48 \\
LEV & 0.411 & 0.386 & 1.21 \\
ROA & -0.06 & 3.15 & $2.58^{* *}$ \\
CoDbt & 8.8 & 6.0 & $1.95^{*}$ \\
FinDis & 1.64 & 2.75 & $2.11^{*}$ \\
\hline
\end{tabular}

Notes: ${ }^{a} \mathrm{OCF}$ is operating cash flows (scaled by lagged total assets) estimated according to the standard set by the Hellenic Capital Market Commission as it is described in decision No. 5/204/2000; LEV is total debt to total assets; ROA is return on total assets; CoDbt is cost of long-term and short-term debt computed as interest expenses to total debt; and FinDis is the Altman-z computed as $1.2 *$ (working capital/total assets) $+1.4^{*}$ (retained earnings/total assets) $+3.3 *$ (earnings before interest and taxes/total assets) $+0.6^{*}$ (market value of equity/book value of total debt) $+1.0 *$ (sales/total assets)

**Significant at a level of $1 \%$; *significant at a level of $5 \%$.

Next, we present the percentage of decrease of earnings that has been calculated by quantifying the qualifications included in the auditors' reports of the 58 suspect firms. It is hardly a surprise that all the cases identified have to do with firms overstating earnings. In this context, Pierre and Anderson (1984) and Palmrose (1988) show that auditors are more likely to be sued if reported profits are alleged to exceed the true earnings. In contrast there is little evidence of auditors being sued if reported profits are less than true earnings. The results can be summarised in Table 2.

Table 2 Effects of auditor qualifications on reported net earnings before tax of 58 'suspect' ASE companies using non-consolidated financial statements - 2002 (columns A-C in thousands of Euros)

\begin{tabular}{lcccc}
\hline Company & $\begin{array}{c}\text { A-Net } \\
\text { earnings } \\
\text { before tax }\end{array}$ & $\begin{array}{c}\text { B-Auditor } \\
\text { qualification } \\
\text { effects }\end{array}$ & $\begin{array}{c}\text { C-Adjusted } \\
\text { net earnings } \\
(A+B)\end{array}$ & $\begin{array}{c}\text { \% Increase (+)/ } \\
\text { decrease (-) } \\
\text { in net earnings } \\
(C-A) / A^{*} 100\end{array}$ \\
\hline IMAKO MEDIA S.A & 107 & -2329 & -2222 & -2.177 \\
ALFA ALFA ENERGY S.A & 733 & $-11,766$ & $-11,033$ & -1.605 \\
PAPERPACK - I. & 310 & -4368 & $-4,058$ & -1.409 \\
TSOUKARIDIS S.A & & & & -1.408 \\
UNIBRAIN S.A & -168 & -2367 & -2535 & -491 \\
O. DARING SAIN & -678 & -3330 & -4008 & -408 \\
EURODRIP S.A & -829 & -3385 & -4214 & -408 \\
MAXIM C. M. PERTSINIDIS & -829 & -3385 & -4214 & -362 \\
TEXAPRET & 554 & -2003 & -1449 & -4.117 \\
Subtotal & -800 & $-32,933$ & $-33,733$ & -40 \\
50 other ASE companies & 169,709 & $-67,862$ & 101,847 & -59.7 \\
TOTAL & 168,909 & $-100,795$ & 68,114 & \\
\hline
\end{tabular}


Surprisingly, by quantifying auditors' qualifications, four quoted companies realised a decrease in their reported earnings by more than $1.400 \%$ while on average the percentage of decrease for all 'suspect' companies approximated $60 \%$.

At this point it is worth noting that most of the practices adopted by Greek companies can be viewed as legal, although they dramatically alter earnings and the image shown by the financial statements. Despite the detailed nature of Greek law, it offers many opportunities for practice of 'legitimate' creative accounting.

Another interesting feature is that by far the most frequent and effective qualification ${ }^{10}$ in the auditors' reports of our 'suspect firms' sample concerns the overstatement of those firms' long-term investments. This fact can be explained by the unseen struggle of mergers \& acquisitions (M\&A) in which Greek listed companies took part, following the euphoria that the increase in the stock exchange brought about in the period around the year 1999, when a waste of capital for the acquisition of overvalued firms as a result of past exaggerated evaluations prevailed.

\section{Hypotheses}

The role of auditors, as stated earlier, is very important in the capital markets system. Independent audits enhance the credibility of financial information and the reliability of this information is essential because resource allocation depends on market activity. Auditors should maintain their role of independence and not be influenced by clients who desire to manage earnings through inappropriate interpretation of the accounting standards. The auditors' primary role is to determine that financial statements are free of errors and use acceptable GAAP and to render an opinion that states whether the statements are free of material misstatements. As a consequence the auditors' opinions are based on the auditors' judgment as to whether the accounting principles selected and applied have general acceptance and are appropriate. A clean opinion therefore signifies greater compliance with GAAP and a higher earnings quality.

However, during recent years, anecdotal evidence in Greece indicates that the amounts in specific accounts (such as earnings and net worth) on the financial statements of Greek firms can change dramatically by the quantification of the qualifications included in the auditor's report. In this sense, it can be argued that Greek accounting rules facilitate managers to provide an opportunistic version of reported earnings by ignoring certain events and using high income-increasing accruals methods. Consequently, for the purposes of this study and consistent with our primary hypothesis, we expect that Greek auditors are aware of potential earnings management and that:

Hypothesis 1: the extent of earnings management, measured by discretionary accruals models, is significantly higher in audited firms that receive opinions with qualifications as opposed to firms receiving 'clean' auditor opinions.

Furthermore, with respect to the intuition of Butler et al. (2004), and based on a measure of financial distress (Altman's $z$-score model) we investigate the possible association between discretionary accruals and probabilities of bankruptcy for our group of 'suspects' for earnings' manipulation companies, since prior evidence indicate that financially distressed firms, receiving either a qualified or a clean report, exhibit large negative accruals. Additionally we anticipate that the size of the auditor qualifications 
is significantly associated with the extent of earnings management and this leads to our second (twofold) hypothesis:

Hypothesis 2(a): Companies which receive audit reports with more severe quantifiable qualifications should be more aggressive earnings manipulators

and

Hypothesis 2(b): Among companies which receive qualified audit reports, the extent of earnings management is significantly higher for companies in financial distress.

\section{Methodology and results}

The main approaches that have been used in the literature to evaluate the existence of earnings management can be broadly classified into three categories: a study of aggregate accruals and the use of regression models to calculate expected and unexpected or discretionary accruals; a focus on specific accruals, such as the provision for bad debts, or on accruals in specific sectors, such as the claim loss reserve in the insurance industry; and finally, an investigation of discontinuities in the distribution of earnings.

In this study, like many other studies, we use the level of discretionary accruals to proxy for the extent of opportunistic earnings management. The standard model used by prior research in attempting to identify discretionary or abnormal accruals is based on Jones (1991). Total accruals are regressed on variables, which are expected to vary with nondiscretionary accruals while the unexplained portion (i.e. the residuals) is interpreted as discretionary accruals. Many Jones-style models have been used either in a time-series ${ }^{11}$ firm-specific framework, or they have been estimated in the cross-section for each industry.

In this paper, for the event year 2002, we alternatively use three competing models to measure accruals. Firstly, we use the well-known cross-sectional model of Jones (1991) in which homogeneity across firms in the same industry is assumed. Next, we use a modified Jones model (Dechow et al., 1995), which assumes that the change in revenues less the change in accounts receivable is free from managerial discretion (i.e. credit sales are assumed to be discretionary). Finally, we use the more recent model of Kothari et al. (2005) which, based on Kasznik's (1999) results that estimated discretionary accruals are correlated with earnings performance, i.e. firms with low (high) earnings tend to have negative (positive) discretionary accruals, suggest the inclusion of a control for firm performance.

To estimate discretionary accruals (DAC), we first compute total accruals (TAC) as income before extraordinary items less operating cash flows. We do not use the total accrual balance sheet approach since according to Hribar and Collins (2002) this approach tends to induce positive bias when M\&A occur and negative bias when discontinued operations occur. Having calculated TAC our models are specified as:

$$
\mathrm{TAC} / A_{t-1}=\alpha\left(1 / A_{t-1}\right)+\beta_{1}\left(\Delta \mathrm{REV} / A_{t-1}\right)+\beta_{2}\left(\mathrm{PPE} / A_{t-1}\right)+e
$$

$$
\mathrm{TAC} / A_{t-1}=\alpha\left(1 / A_{t-1}\right)+\beta_{1}\left(\Delta \mathrm{REV}-\Delta \mathrm{REC} / A_{t-1}\right)+\beta_{2}\left(\mathrm{PPE} / A_{t-1}\right)+e
$$




$$
\begin{aligned}
\mathrm{TAC} / A_{t-1}= & \alpha\left(1 / A_{t-1}\right)+\beta_{1}\left(\Delta \mathrm{REV}-\Delta \mathrm{REC} / A_{t-1}\right) \\
& +\beta_{2}\left(\mathrm{PPE} / A_{t-1}\right)+\beta_{3}\left(\mathrm{ROA}_{t-1} / A_{t-1}\right)+e
\end{aligned}
$$

where: TAC is total accruals (income before extraordinary items less operating cash flows) for firm $i$ in year $t$ (2002); $A_{t-1}$ is total assets for firm $\mathrm{i}$ in year $t-1 ; \Delta \mathrm{REV}$ is the change in net revenues for firm $i$ in year $t, \triangle \mathrm{REC}$ is change in accounts receivables for firm $i$ in year $t$; PPE is gross property, plant and equipment for firm $i$ and year $t$; and $\mathrm{ROA}_{t-1}$ is return on assets for firm $i$ in year $t-1$.

For year 2002 and industries, we estimate regression parameters in Equations (1)-(3) using cross-sectional observations from our sample of non-suspect firms. Following the industry classification of the ASE, we classify all firms into nine industries. ${ }^{12}$ To obtain meaningful cross-sectional estimates of regression parameters, we require that at least 10 firms exist for each industry in the event year 2002. Discretionary or abnormal accruals are determined as the prediction error terms that are the difference between the predicted accruals using the parameter estimates from the three equations, and reported accruals for each test sample of suspect firms following industries' categorisation. Specifically, discretionary accruals are the prediction errors of the above accrual models where $a, b_{1}$, $b_{2}, b_{3}$ are parameter estimates of $\alpha, \beta_{1}, \beta_{2}, \beta_{3}$ in:

$$
\begin{gathered}
\mathrm{DAC}_{i t}=\mathrm{TAC} / A_{t-1}-a\left(1 / A_{t-1}\right)+b_{1}\left(\Delta \mathrm{REV} / A_{t-1}\right)+b_{2}\left(\mathrm{PPE} / A_{t-1}\right) \\
\mathrm{DAC}_{i t}=\mathrm{TAC} / A_{t-1}-a\left(1 / A_{t-1}\right)+b_{1}\left(\Delta \mathrm{REV}-\Delta \mathrm{REC} / A_{t-1}\right)+b_{2}\left(\mathrm{PPE} / A_{t-1}\right) \\
\mathrm{DAC}_{i t}=\mathrm{TAC} / A_{t-1}-a\left(1 / A_{t-1}\right)+b_{1}\left(\Delta \mathrm{REV}-\Delta \mathrm{REC} / A_{t-1}\right) \\
+b_{2}\left(\mathrm{PPE} / A_{t-1}\right)+b_{3}\left(\mathrm{ROA}_{t-1} / A_{t-1}\right)
\end{gathered}
$$

The estimation results (not reported here) show that the coefficients are generally in the expected region. ${ }^{13}$ Following prior research, we alternatively use the absolute value of unexpected accruals in all previous equations as a proxy for financial reporting quality. According to Reynolds and Francis (2000) the magnitude of absolute value of unexpected accruals measures a company's success in managing earnings either up or down depending on year specific situations. In all cases, a significant value of DAC or absolute DAC is viewed as earnings management. Table 3 reports on the magnitude of discretionary accruals for the full sample.

Consistent with our first hypothesis, as clearly shown in Panel A of Table 3, almost all competing models indicate a statistically significant level of abnormal accruals for the 'suspect' firms. As one would expect in all cases the level of absolute discretionary accruals proved to be higher than signed discretionary accruals. On the other hand, discretionary accruals of non-suspect firms (Panel B), which constitute our neutral sample, seem to be insignificantly low. 
Table 3 DAC of sample firms $(n=276)$

\begin{tabular}{|c|c|c|c|c|c|c|}
\hline $\begin{array}{l}\text { Discretionary } \\
\text { accruals }\end{array}$ & $\begin{array}{c}\text { Jones model } \\
\text { Equation } 4\end{array}$ & $\begin{array}{c}\text { Jones model } \\
\text { (DAC } \\
\text { absolute } \\
\text { values) }\end{array}$ & $\begin{array}{l}\text { Dechow } \\
\text { model } \\
\text { Equation } 5\end{array}$ & $\begin{array}{c}\text { Dechow } \\
\text { model (DAC } \\
\text { absolute } \\
\text { values) }\end{array}$ & $\begin{array}{c}\text { Kothari } \\
\text { model } \\
\text { Equation } 6\end{array}$ & $\begin{array}{c}\text { Kothari } \\
\text { model }\end{array}$ \\
\hline \multicolumn{7}{|c|}{ Panel $A-D A C$ of 'suspect' firms $-n=58$} \\
\hline Mean & 0.04 & 1.89 & -0.37 & 1.71 & 1.45 & 3.16 \\
\hline$t$-test & $2.13^{*}$ & $2.16^{*}$ & $1.94 *$ & $1.99 *$ & 1.64 & $2.22 *$ \\
\hline Minimum & -11.82 & 0.19 & -17.08 & 0.08 & -37.41 & 0.56 \\
\hline Maximum & 28.64 & 28.64 & 39.12 & 39.12 & 79.38 & 79.38 \\
\hline \multicolumn{7}{|c|}{ Panel B - DAC of 'non-suspect' firms $-n=218$} \\
\hline Mean & 0.01 & 1.03 & -0.48 & -0.81 & 1.17 & 0.95 \\
\hline$t$-test & 0.76 & 1.22 & 1.01 & 0.82 & 1.13 & 0.87 \\
\hline Minimum & -12.44 & 0.21 & -12.97 & 0.10 & -33.43 & 0.31 \\
\hline Maximum & 25.64 & 25.64 & 23.50 & 23.50 & 46.42 & 46.42 \\
\hline
\end{tabular}

Notes **Significant at a level of $1 \%$; *significant at a level of $5 \%$

Having calculated abnormal accruals, our purpose is to investigate their possible relation to the size of the auditor qualifications and to financial distress assuming in essence that firms with more severe qualifications and higher probability of bankruptcy, proxied by Altmans' $z$-score model (1968), would engage in earnings management to a greater extent. We also include several control variables in the above equations that may affect the level of discretionary accruals. Previous research documents a negative correlation between DAC and cash flow performance (Becker et al., 1998; Dechow et al., 1995; Kim et al., 2003). We thus include operating cash flows scaled by lagged total assets (OCF) in Equation (7) below to control for the potential confounding effects of OCF on our results. We also include return on assets (ROA) and the ratio of total debts to total assets (LEV) as control variables because previous research suggests they may affect discretionary accrual choices in the current period. Finally, given that increased credibility of audited information has been shown to result in the lower cost of capital (Yu, 2005, refers to a transparency spread in bond markets) for firms that receive clean opinions (Bamber and Stratton, 1997; Blackwell et al., 1998), we use the ratio of total bank debts to interest expenses. We expect that bankers, as senior debt claimants, can serve as a third party certification of the firm and provide a monitoring function as senior debt holders. Therefore, we examine the relation between discretionary accruals and credit spreads. If the information content of audits is incorporated in credit rating assessments, as must be the case since bankers are considered as sophisticated users of financial statements, we expect higher degrees of discretionary accruals to be associated with higher credit spreads.

Multiple regressions are estimated according to the following equation:

$$
\begin{aligned}
\mathrm{DAC}_{i t}\left(\text { or }\left|\mathrm{DAC}_{i t}\right|\right)= & \alpha+\beta_{1} O C F_{i t}+\beta_{2} L E V_{i t}+\beta_{3} \mathrm{CoDbt}_{i t} \\
& +\beta_{4} \mathrm{FinDis}_{i t}+\beta_{5} \mathrm{SAQ}_{i t}+\varepsilon_{i t}
\end{aligned}
$$


where, for firm $i$ and year $t$ (2002):DAC ${ }_{i t}$ is accruals computed using Equations (4)-(6); $\left|\mathrm{DAC}_{i t}\right|$ is the absolute level of discretionary accruals computed as variations of Equations (4)-(6) respectively; $\mathrm{OCF}_{i t}$ is operating cash flows scaled by total assets; $\mathrm{LEV}_{i t}$ is the ratio of total debts to total assets; $\mathrm{CoDbt}_{i t}$ is bank debts divided by interest expenses; FinDis ${ }_{i t}$ is Altmans' $z$-score; $\mathrm{ROA}_{i t}$ is return on assets; SAQ is size of auditor qualifications; and $\varepsilon_{i t}$ is an error term.

All regressions gave us qualitatively similar results. In Table 4 we report the regression estimates of the three competitive models. The most robust and meaningful regression model stems by utilising the absolute abnormal accruals estimated from Jones model.

Table 4 Cross sectional regression results measuring $|\mathrm{DAC}|$ using various models

\begin{tabular}{lccc}
\hline Absolute discretionary accruals & \multicolumn{3}{c}{ Coefficients } \\
\cline { 2 - 4 } Independent variables & Jones model & Dechow model & Kothari model \\
\hline Constant & $1.92(1.64)$ & $2.26(1.97)^{*}$ & $2.55(1.95)^{*}$ \\
OCF & $-0.82(-1.91)^{*}$ & $-0.43(0.86)$ & $-1.84(1.66)$ \\
LEV & $0.77(1.63)$ & $1.35(1.10)$ & $1.66(1.57)$ \\
CoDbt & $0.45(0.74)$ & $0.06(1.08)$ & $2.00(1.42)$ \\
FinDis & $-0.32(-2.11)^{*}$ & $0.53(0.74)$ & $0.18(0.97)$ \\
ROA & $0.89(1.38)$ & $0.31(1.17)$ & $0.04(0.39)$ \\
SAQ & $0.28(1.94)^{*}$ & $1.67(0.34)$ & $1.49(0.46)$ \\
Number of observations & 58 & 58 & 58 \\
Adjusted $R^{2}$ & 0.31 & 0.16 & 0.24 \\
\hline
\end{tabular}

Notes: ${ }^{* *}$ Significant at a level of $1 \%$; * significant at a level of $5 \%$

Our primary interest is in $\beta_{4}$ and $\beta_{5}$. The coefficient on FinDis is significant with a negative sign. This is consistent with the overall findings of Butler et al. (2004) indicating that companies with lower $z$-scores (higher financial distress) exhibit higher levels of unexpected or abnormal accruals.

As it was also expected there is a positive effect of the size of the auditor qualifications to the magnitude of earnings management adopted by firms with qualified reports. It is therefore apparent that the Greek accounting standards offer ample room for creativity since in most cases Greek firms just exploit the weaknesses of the law without violating it (legitimate creative accounting). Moreover, in the absence of an institutional authority and framework to supervise the procedure of quantifying the auditors' qualifications, the role of auditors is limited in just qualifying their reports. However, even so, Greek auditors as evidenced play a significant role by warning through their opinion all financial statement users for firms which adopt aggressive accounting policies.

Consistent with the theoretical formulation, DAC is also positively associated with ROA but this is not significant, while the relation between DAC and LEV, is (almost) significantly positive since it has been found that managers of high leverage firms have incentives to adopt an income-increasing discretionary accruals policy. This 
positive relation however is inconsistent with the debt-monitoring hypothesis that outside debt suppliers, primarily commercial banks, monitor managerial opportunism such as opportunistic earnings management. Next, similar to Becker et al. (1998) who documented a negative association of OCF with DAC, we report a statistically significant negative coefficient for this relation. Unlike our predictions, finally, the CoDbt variable, even if it has the expected sign, did not prove significant, indicating that earnings management techniques do not influence substantially the pricing process followed by Greek banks.

\section{Conclusion}

In this paper we examine the usefulness of accounting information and information included in auditors' reports in detecting the earnings management behaviour of 'suspect' firms forced to restate earnings. Earnings restatement firms represent an ideal setting to examine earnings management.

Utilising a sample of 91 identified by the ASE 'suspect' listed firms, we show that audited reports with remarkable qualified opinions contain substantially managed published earnings an event which is related to higher probabilities of bankruptcy for these companies. In this sense our study adds evidence from a small country to the mixed results concerning the possible effect of financial distress condition in companies' accruals policy.

Our findings are of particular interest for the Greek regulators since it is apparent that the Greek law, despite its detailed and restrictive nature, does offer many opportunities for earnings manipulation to the Greek companies either by exploiting the weaknesses of the GAAP or by violating them. Collectively, the evidence suggests that market participants can gain substantial value from a careful consideration of information in auditors' reports by quantifying the auditor qualifications and incorporating the inferences in their analysis.

This study suggests opportunities for further research. Firstly within the limitations of the paper, it would be possible to extend the analysis further to cover both a longer period of time and a larger number of companies including non-listed firms, since different motivations (i.e. tax avoidance) may reveal different forms of creativity applied by these firms. Secondly, following previous international studies (Choi and Jeter, 1992; Loudder et al., 1992) it would be interesting to investigate the association between audit qualifications and stock returns of suspect firms so as to examine whether or not investors perceive qualified audit reports as informative.

\section{Acknowledgements}

The authors are indebted to Professor Dimitrios Ghicas for his valuable comments and suggestions. An early version of this paper was presented at the third Annual Conference of the Hellenic Finance and Accounting Association held in Athens, Greece on December 3-4, 2004. We thank conference participants and especially Professors Stavros Thomadakis and Charalambos Spathis for their suggestions. 


\section{References}

Altman, E. (1968) 'Financial ratios, discriminant analysis and the prediction of corporate bankruptcy', Journal of Finance, September, pp.589-609.

Ballas, A. (1999) 'Privatising the statutory auditing services in Greece', Accounting, Business \& Financial History, Vol. 9, No. 3, pp.349-373.

Bamber, E.M. and Stratton, R.A. (1997) 'The information content of the uncertainty-modified audit report: evidence from bank loan officers', Accounting Horizons, Vol. 11, No. 2, pp.1-11.

Bartov, E., Gul, F. and Tsui, J. (2000) 'Discretionary-accruals models and audit qualifications', Journal of Accounting and Economics, Vol. 30, pp.421-452.

Bauwhede, H., Willekens, M. and Gaeremynck, A. (2000) 'Audit quality, public ownership and firms' discretionary accruals management', Working Paper, Catholic University of Leuven, Department of Applied Economics.

Becker, C.L., DeFond, M.L., Jiambalvo, J. and Subramanyam, K.R. (1998) 'The effect of audit quality on earnings management', Contemporary Accounting Research, Vol. 15, No. 1, pp.1-21.

Bhattacharya, U., Daouk, H. and Welker, M. (2003) 'The world price of earnings opacity', The Accounting Review, Vol. 78, pp.641-678.

Blackwell, D.W., Nolandt, T.R. and Winters, D.B. (1998) 'The value of auditor assurance: evidence from loan pricing', Journal of Accounting Research, Vol. 36 (Spring), pp.57-70.

Bradshaw, M., Richardson, S. and Sloan, R. (2001) 'Do analysts and auditors use information in accruals?', Journal of Accounting Research, Vol. 39, pp.45-74.

Butler, M., Leone, A. and Willenborg, M. (2004) 'An empirical analysis of auditor reporting and its association with abnormal accruals', Journal of Accounting and Economics, Vol. 37, pp.139-165.

Caramanis, C.V. (1998) 'Assessing the impact of 'liberalization' on auditor behaviour: accounting research in politically charged contexts', Accounting, Auditing \& Accountability Journal, Vol. 11, No. 5, pp.562-592.

Caramanis, C.V. (1999) 'International accounting reforms versus indigenous auditors: intra-professional conflict in the Greek auditing profession 1990-1993', Critical Perspectives on Accounting, Vol. 10, pp.153-196.

Choi, S.K. and Jeter, D.C. (1992) 'The effect of qualified audit opinion on earnings response coefficients', Journal of Accounting and Economics, Vol. 14, pp.229-247.

Chung, R., Firth, M. and Kim, J-B. (2005) 'Earnings management, surplus free cash flow, and external monitoring', Journal of Business Research, Vol. 58, pp.766-776.

Cohen, S., Papadaki, A. and Siougle, G. (2004) 'SEOs in a Hot Market: evidence of timing', Proceedings of Third Conference of Hellenic Finance and Accounting Association, 3-4 December, Athens, Greece.

DeAngelo, L.E. (1981) 'Auditor size and audit quality', Journal of Accounting and Economics, Vol. 3, pp.183-199.

Dechow, P.M. and Skinner, D. (2000) 'Earnings management: reconciling the views of accounting academics, practitioners, and regulators', Accounting Horizons, Vol. 14, pp.235-250.

Dechow, P.M., Sloan, R.G. and Sweeney, A.P. (1995) 'Detecting earnings management', The Accounting Review, Vol. 70, pp.193-225.

Francis, J. and Krishnan, J. (1999) 'Accounting accruals and auditor reporting conservatism', Contemporary Accounting Research, Vol. 16, pp.135-165.

Healy, P. and Wahlen, J.M. (1999) 'A review of the earnings management literature and its implications for standard setting', Accounting Horizons, Vol. 13, pp.365-383. 
Hirst, D.E. (1994) 'Auditor sensitivity to earnings management', Contemporary Accounting Research, Vol. 11, pp.405-422.

Hribar, P. and Collins, D. (2002) 'Errors in estimating accruals: Implications for empirical research', Journal of Accounting Research, Vol. 40, pp.102-134.

Jones, J. (1991) 'Earnings management during import relief investigations', Journal of Accounting Research, Vol. 29, pp.193-228.

Kasznik, R. (1999) 'On the association between voluntary disclosure and earnings management', Journal of Accounting Research, Vol. 37, pp.57-81.

Kim, J-B., Chung, R. and Firth, M. (2003) 'Auditor conservatism, asymmetric monitoring and earnings management', Contemporary Accounting Research, Vol. 20, pp.323-360.

Kinney, W. and Martin, R. (1994) 'Does auditing reduce bias in financial reporting? A review of audit-related adjustment studies', Auditing: A Journal of Practice and Theory, Vol. 13, pp.149-156.

Kothari, S.P., Leone, A.J. and Wasley, C.E. (2005) 'Performance-matched discretionary accrual measures', Journal of Accounting and Economics, Vol. 39, pp.163-197.

Koumanakos, E. and Tzelepis, D. (2004) 'Earnings management Initial Public Offerings in Greece', Proceedings of the 27th Annual Congress of the European Accounting Association, April 1-3, Prague, Czech Republic.

Koumanakos, E., Siriopoulos, C. and Georgopoulos, A. (2005) 'Firm acquisitions and earnings management: evidence from Greece', Managerial Auditing Journal, Vol. 20, pp.663-678.

Leuz, C., Nanda, D. and Wysocki, P. (2003) 'Earnings management and investor protection: an international comparison', Journal of Financial Economics, Vol. 69, pp.505-527.

Loudder, M.L., Khurana, I.K., Sawyers, R.B., Cordery, C., Johnson, C., Lowe, J. and Wunderle, R. (1992) 'The information content of audit qualifications', Auditing: A Journal of Practice \& Theory, Vol. 11, pp.69-82.

Nelson, M., Elliott, J. and Tarpley, R. (2002) 'Evidence from auditors about managers' and auditors' earnings management decisions', The Accounting Review, Vol. 77, pp.175-202.

Oltheten, E., Pinteris, G. and Sougiannis, T. (2003) 'Greece in the European Union: policy lessons from two decades of membership', The Quarterly Review of Economics and Finance, Vol. 43, pp.774-806.

Palmrose, Z. (1988) 'An analysis of auditor litigation and audit service quality', The Accounting Review, Vol. 63, pp.55-73.

Pierre, S. and Anderson, J. (1984) 'An analysis of the factors associated with lawsuits against public accountants', The Accounting Review, Vol. 59, pp.242-263.

Reynolds, K. and Francis, J. (2000) 'Does size matter? The influence of large clients on office level auditor reporting decisions', Journal of Accounting and Economics, Vol. 30, pp.375-400.

Roosenboom, P., Van der Goot, T. and Mertens, G. (2003) 'Earnings management and initial public offerings: evidence from the Netherlands', The International Journal of Accounting, Vol. 38, pp.243-266.

Shen, C-H. and Chih, H-L. (2005) 'Investor protection, prospect theory, and earnings management: an international comparison of the banking industry', Journal of Banking and Finance, in press.

Spathis, C. (2003) 'Audit qualification, firm litigation, and financial information: an empirical analysis in Greece', International Journal of Auditing, Vol. 7, pp.71-85.

Spathis, C., Doumpos, M. and Zopounidis, C. (2003) 'Using client performance measures to identify pre-engagement factors associated with qualified audit reports in Greece', The International Journal of Accounting,Vol. 38, pp.267-284.

Teoh, S.H., Welch, I. and Wong, T.J. (1998) 'Earnings management and the long run market performance of initial public offerings', The Journal of Finance, Vol. 53, pp.1935-1974.

$\mathrm{Yu}, \mathrm{F}$. (2005) 'Accounting transparency and the term structure of credit spreads', Journal of Financial Economics, Vol. 75, pp.53-84. 


\section{Notes}

1 See Dechow and Skinner (2000) for a review.

2 We do not include the international study (across 48 countries) of Shen and Chih (2005) who tested if earnings management exists in the banking sector and found that Greek banks manage their earnings to exceed thresholds but not to an exaggerated degree.

3 Bhattacharya et al. (2003) defined earnings opacity of a country as the extent to which the distribution of the reported earnings of firms in that country fails to provide information about the distribution of the true, but unobservable, economic earnings of firms in that country. According to them, reported earnings in a country could be opaque because of a complex interaction among, at least, three factors: managerial motivation, accounting standards and audit quality.

4 Greek listed companies, in common with all others in the European Union, are obliged since 2005 to report under international accounting standards. A decision has also been taken to extend this reporting requirement to all unlisted companies by 2009 .

5 In the Greek context, audit is made in accordance to the business law L 2190/1920 as well as in accordance to the standards followed by the Greek Institute of Certified Public Accountants. However, the fact that some accounting issues that are arranged by law L 2190/1920 are also differently arranged by others laws (i.e. L 2238/1994 or P.D. 186/1992) gives the opportunity to many firms not to prepare their financial statements according to L $2190 / 1920$. The auditors would remark on this in their reports.

6 Cases of adverse opinion and disclaimer of opinion are very rare.

7 However, it has been observed that analysts' reports in Greece usually fail to mention the existence of audit report qualifications or other manifestation of earnings management.

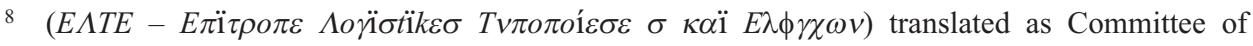
Accounting Standardisation and Control.

9 Web address: http://www.ase.gr/content/gr/Companies/ListedCo/Financial_Statements/Financial Statements_June2003.asp.

10 Other frequently reported and effective qualifications identified in the sample of suspect firms had mainly to do with inadequate provisions for bad debts and employee compensation owing to retirement as well as inaccurate estimation of taxes payable.

11 A limitation of the time-series approach is its data requirements.

12 The nine industries used are the following: Wholesale trade; Retail trade; Food; Textiles; Paper \& Printing; Construction; Metals; Information Technology and an aggregate of remain industries.

13 The expected sign for property, plant and equipment is a priori negative, the expected sign for change in revenue or change in revenue net of accounts receivable is more difficult to establish a priori (Jones, 1991) while the expected sign for performance is positive. 